\title{
Effect of silicon chelates from plant raw materials on some physiological parameters in strawberry under in vitro conditions
}

\author{
$E$ Ambros $^{1, *}, E$ Trofimova $^{2}$, and $T$ Novikova $^{1}$ \\ ${ }^{1}$ Central Siberian Botanical Garden, Siberian Branch of the Russian Academy of Sciences, \\ Novosibirsk, st. Zolotodolinskaya, 101, 630090, Russian Federation \\ ${ }^{2}$ Institute of Solid State Chemistry and Mechanochemistry, Siberian Branch of the Russian Academy \\ of Sciences, st. Kutateladze, 18, Novosibirsk, 630128, Russian Federation
}

\begin{abstract}
For the first time, the effect mechanocomposite based on biogenic silica and green tea flavonoids (MC) on reduction of oxidative stress in microshoots of strawberry plantlets (cv. "Solnechnaya polyanka") during in vitro multiplication, shoot elongation and rooting stages were established. Compared with the plantlets cultured in MC-free media, the ones cultured in media supplemented with MC showed increased key antioxidant enzyme activities (superoxide dismutase - SOD, peroxidase POD, catalase - CAT). SOD activity increased from 1.1 to 1.4 times at 2.5 and $5.0 \mathrm{mg} \mathrm{L}-1 \mathrm{MC}$, POD activity - from 1.8 to 3.8 times at 5.0 and 10.0 $\mathrm{mg} \mathrm{L}-1 \mathrm{MC}$, and CAT activity - from 1.1 to 1.4 times at $5.0 \mathrm{mg} \mathrm{L}-1 \mathrm{MC}$ depending on the stage of micropropagation. The high antioxidant enzyme activities correlated with the decrease of $\mathrm{H} 2 \mathrm{O} 2$ content (up to 1.7 times compared with the control). The revealed changes in the physiological status of strawberry plantlets in the presence of MC contribute to the further successful acclimatization of regenerants to ex vitro conditions. Thus, these results have demonstrated the potential of "green chemistry" for the production of healthy plant material of strawberry cultivars.
\end{abstract}

\section{Introduction}

The world production and consumption of cultivated strawberry (Fragaria $\times$ ananassa Duch.) is increasing very fast. According to Faostat, about 9 million tons of fresh strawberry berries were grown and sold globally in 2017. In this regard, in vitro techniques are important tools for obtaining virus, bacteria and fungus-free strawberry basic planting material [1]. However growth and development of plants in in vitro conditions are stressrelated processes which are accompanied by changing of metabolic reactions. Unfavourable in vitro factors (high relative humidity, low gas exchange, presence of exogenous carbohydrates, plant growth regulators and low rate of $\mathrm{CO}_{2}$ absorption) shift the balance between oxidants and antioxidants toward oxidants, which stimulate development of intracellular oxidative stress [2]. Symptoms of the stress in in vitro conditions include a

\footnotetext{
*Corresponding author: ambros_ev@ mail.ru
} 
reduction of culture growth, inhibition of shoots, roots proliferation, culture ageing and finally cell necrosis. To achieve physiological stability of cultivated plant, the culture medium is optimized by the addition of exogenous compounds with antioxidant properties that activate the antioxidant (non- and enzymatic) defense systems in plant tissues to scavenge reactive oxygen species. In this regard, the selection of antioxidant preparations that minimize the oxidative processes in cells is a necessary step in micropropagation protocols.

A promising preparation is the mechanocomposite obtained from renewable plant raw materials (rice husk and green tea waste) [3]. Rice husk is a renewable source of amorphous silicon dioxide (silica) with a content of up to $29 \%$ by weight [4-5]. Green tea is rich in the flavanol group of polyphenols as catechins which may constitute up to $30 \%$ of the dry weight [6]. In previous studies, we have shown the growth-regulating and adaptogenic activities of the mechanocomposite based on biogenic silica and green tea flavonoids at the stages of in vitro rooting and ex vitro acclimatization of $F . \times$ ananassa plantlets [7-8]. Since mechanocomposite contains silicon compounds and catechins with antioxidant properties [9-10], in this work, for the first time, the potential antioxidant protective effect, including superoxide dismutase, catalase, and peroxidase enzymes, of this environmentally friendly preparation will be analyzed under micropropagation of strawberry. The use of "green chemistry" (mechanocomposite) as an inhibitor of in vitro stresses may become a technology recognized and in demand at the world.

Thus, in the present study we aimed to analyze the effect of different concentrations of mechanocomposite on the physiological parameters in strawberry plantlets under in vitro conditions, including the content of hydrogen peroxide $\left(\mathrm{H}_{2} \mathrm{O}_{2}\right)$ and activity of key antioxidant enzymes (superoxide dismutase (SOD), catalase (CAT), peroxidase (POD)).

\section{Materials and methods}

\subsection{Plant material and growth conditions}

The physiological parameters of micropropagated plantlets of strawberry cultivar, 'Solnechnaya polyanka', under the influence of mechanocomposite during in vitro multiplication, shoot elongation and rooting stages were studied. The explants were cultivated on Gamborg-Eveleg's basal salt medium - $\mathrm{B}_{5}$ [11] containing $20 \mathrm{~g} \mathrm{~L}^{-1}$ sucrose, 6 $\mathrm{g} \mathrm{L}^{-1}$ Bactoagar (PanReac ${ }^{\circledR}$, Spain) at all in vitro stages. To induce shoot multiplication, the microshoots $(1.0 \mathrm{~cm})$ with apical bud and two leaves were inoculated on medium supplemented with $0.75 \mathrm{mg} \mathrm{L}^{-1}$ 6-benzylaminopurine (BA; ICN Biomedicals, Aurora, $\mathrm{OH}$ ), and different concentrations of $\mathrm{MC}\left(0.0,2.5,5.0\right.$ or $\left.10.0 \mathrm{mg} \mathrm{L}^{-1}\right)$. After 60 days, conglomerates with microshoots were placed on shoot elongation medium supplemented with $0.0,2.5,5.0$ or $10.0 \mathrm{mg} \mathrm{L}^{-1}$ of MC and were cultured for 45 days. After that plantlets were transferred to rooting medium supplemented with the same MC concentrations for 30 days. The MC-free medium was used as the control. All media were adjusted to pH 5.5 before autoclaving $\left(121^{\circ} \mathrm{C}, 2.1 \mathrm{~atm}\right.$ for $\left.20 \mathrm{~min}\right)$, and $\mathrm{MC}$ was added to the media before autoclaving. The cultures were maintained in culture jars ( $15 \mathrm{~mL}$ medium per vessel) at 23 $\pm 2{ }^{\circ} \mathrm{C}$ with a 16 -h photoperiod with $40 \mu \mathrm{mol} \mathrm{m} \mathrm{m}^{-2} \mathrm{~s}^{-1}$ of light intensity provided by cool white fluorescent lamps (Philips, Pila, Poland). Experiments were repeated thrice, and 30 microshoots were used for each $\mathrm{MC}$ concentration. At the end of the each cultivation period the endogenous $\mathrm{H}_{2} \mathrm{O}_{2}$ content and antioxidant enzyme activities were analyzed. 


\subsection{Biochemical analysis}

The endogenous $\mathrm{H}_{2} \mathrm{O}_{2}$ level was analyzed using the standard $\mathrm{H}_{2} \mathrm{O}_{2}$ calibration curve at 560 $\mathrm{nm}$ according to Bellincampi et al. [12]. Data were expressed as $\mu \mathrm{mol} \mathrm{H}_{2} \mathrm{O}_{2}$ per gram of fresh weight $(\mathrm{FW})\left(\mu \mathrm{mol} \mathrm{g} \mathrm{g}^{-1}(\mathrm{FW})\right.$. To determine the antioxidant enzyme activities, about $0.1 \mathrm{~g}$ fresh shoot tissue was extracted in $50 \mathrm{mM} \mathrm{Na}-\mathrm{K}$-phosphate $(\mathrm{pH} 7.8)$ containing 100 $\mathrm{mM}$ phenylmethylsulphonyl fluoride. Then the homogenate was centrifuged at $12,000 \mathrm{rpm}$ for $5 \mathrm{~min}$ at $4{ }^{\circ} \mathrm{C}$ and the supernatant was used for determination of the superoxide dismutase (SOD) and catalase (CAT) activities. Absorbance of samples was recorded using a SF-56 spectrophotometer (OKB-Spectr, Russia). Determination of SOD activity was performed by the enzyme's ability to inhibit the photochemical reduction of nitro blue tetrazolium as previously described by C. N. Giannopolitis and S. K. Ries with minor modifications [13]. The absorbance was measured at $560 \mathrm{~nm}$ and expressed in units (U) per gram of $\mathrm{FW}\left(\mathrm{U} \mathrm{g}^{-1}(\mathrm{FW})\right)$. CAT activity was determined by the decrease in optical density as a result of the decomposition of $\mathrm{H}_{2} \mathrm{O}_{2}$ at $240 \mathrm{~nm}$ [14] and expressed in units of $\mathrm{H}_{2} \mathrm{O}_{2}$ decomposed per min per $\mathrm{g}$ of fresh weight $\left(\mathrm{U} \mathrm{H}_{2} \mathrm{O}_{2} \mathrm{~g}^{-1}(\mathrm{FW}) \mathrm{min}^{-1}\right)$. For the analysis of peroxidase activity (POD) about $50 \mathrm{mg}$ shoot tissues were macerated in $0.2 \mathrm{M}$ acetate buffer ( $\mathrm{pH} 4.5)$. After centrifugation $\left(4^{\circ} \mathrm{C}, 12,000 \mathrm{rpm}, 5 \mathrm{~min}\right)$, the supernatant was collected and immediately POD activity was measured by the decrease in the content of quercetin at $365 \mathrm{~nm}$ [15]. POD activity was expressed as $U$ of quercetin oxidized per min per $\mathrm{g}$ of $\mathrm{FW}\left(\mathrm{U} \mathrm{g}^{-1}(\mathrm{FW}) \mathrm{min}^{-1}\right)$. Three biological and three analytical replications were performed for each analysis.

\subsection{Statistical analysis}

Data were expressed as means and standard errors $(\mathrm{M} \pm \mathrm{SE})$. The data were subjected to a one-way analysis of variance (ANOVA) and the Duncan multiple range test was used to calculate significant differences at $p<0.05$. Statistical evaluations were performed using Statistica 10.0 software (Statsoft Inc., Tulsa, OK, USA).

\section{Results}

\subsection{Effect of $\mathrm{MC}$ on $\mathrm{H}_{2} \mathrm{O}_{2}$ content}

A time dependent variation in the $\mathrm{H}_{2} \mathrm{O}_{2}$ content was found in the plantlets during in vitro shoot multiplication, shoot elongation and rooting stages (Table 1). An increased $\mathrm{H}_{2} \mathrm{O}_{2}$ content was observed in the plantlets at shoot multiplication and rooting stages. However, at shoot elongation stage, a decreasing trend was observed in $\mathrm{H}_{2} \mathrm{O}_{2}$ content up to in vitro rooting stage. At multiplication stage, the accumulation of $\mathrm{H}_{2} \mathrm{O}_{2}$ in the shoots was reduced by the addition of $10.0 \mathrm{mg} \mathrm{L}^{-1} \mathrm{MC}$ by 1.5 times compared with the control $(\mathrm{p} \leq 0.05)$. During the shoot elongation, $\mathrm{H}_{2} \mathrm{O}_{2}$ content significantly decreased under the influence of all $\mathrm{MC}$ concentrations. At in vitro rooting, the $\mathrm{H}_{2} \mathrm{O}_{2}$ content in shoots growing in the presence of 5.0 and $10.0 \mathrm{mg} \mathrm{L}^{-1} \mathrm{MC}$ was 1.7 -fold lower than on control medium. 
Table 1. Changes in $\mathrm{H}_{2} \mathrm{O}_{2}$ content ( $\mu \mathrm{mol} \mathrm{g} \mathrm{g}^{-1}$ (FW) in microshoots of strawberry plantlets (cv. "Solnechnaya polaynka") cultivated in vitro with different mechanocomposite concentrations during the shoot multiplication (SMS, after $60 \mathrm{~d}$ ), shoot elongation (SES, after $105 \mathrm{~d}$ ) and rooting stages

(RS, after $135 \mathrm{~d}$ ).

\begin{tabular}{|c|c|c|c|}
\hline MC* $^{*} \mathrm{mg} \mathrm{L}^{-1}$ & SMS & SES & RS \\
\hline 0.0 & $4.23 \pm 0.01 \mathrm{a}$ & $1.69 \pm 0.06 \mathrm{a}$ & $8.17 \pm 0.76 \mathrm{a}$ \\
\hline 2.5 & $4.17 \pm 0.14 \mathrm{a}$ & $0.91 \pm 0.02 \mathrm{c}$ & $6.22 \pm 0.85 \mathrm{~b}$ \\
\hline 5.0 & $4.09 \pm 0.08 \mathrm{a}$ & $1.50 \pm 0.01 \mathrm{~b}$ & $4.87 \pm 0.04 \mathrm{c}$ \\
\hline 10.0 & $2.86 \pm 0.12 \mathrm{~b}$ & $1.56 \pm 0.01 \mathrm{~b}$ & $4.74 \pm 0.54 \mathrm{c}$ \\
\hline $\begin{array}{c}\text { *MC, mechanocomposite based on amorphous silica and flavonoids of green tea. Data are mean } \pm \\
\text { SE (n=3). For each cultivar and variable, a single-factor analysis of variance was performed } \\
\text { between means. Within a column, mean separation are indicated by different lowercase letters and } \\
\text { determined by Duncan's multiple range test ( } \leq 0.05) .\end{array}$ \\
\hline
\end{tabular}

\subsection{Effect of MC on antioxidant enzyme activities}

According to the data, SOD and CAT activities in microshoots increased significantly during the multiplication and elongation stages (Table 2). Moreover, SOD activity in shoots was extremely high at the elongation stage. At the rooting stage, their activities decreased. The application of MC had a significant influence on antioxidant enzyme activities in the strawberry shoots. The greatest SOD and CAT activities occurred in microshoots on media supplemented with 2.5 and $5.0 \mathrm{mg} \mathrm{L}^{-1} \mathrm{MC}$. In particular, SOD activity increased up to 1.4 times, CAT activity - up to 1.8 times compared with the variants without MC. There was no noticeable change observed in POD activity in the microshoots during studied stages of micropropagation. Increasing POD activity in the microshoots was observed at 5.0 and 10.0 $\mathrm{mg} \mathrm{L}^{-1} \mathrm{MC}(\mathrm{p} \leq 0.05)$ by 2.9 and 3.4 times during the shoot multiplication, by 2.2 and 1.8 times, respectively, during elongation stages. The data indicated that $\mathrm{MC}$ could markedly increase the antioxidant ability of plantlets.

Table 2. Changes in SOD $\left(\mathrm{U} \mathrm{g}^{-1}(\mathrm{FW})\right)$, CAT $\left(\mathrm{U} \mathrm{H}_{2} \mathrm{O}_{2} \mathrm{~g}^{-1}(\mathrm{FW}) \mathrm{min}^{-1}\right)$, and POD $\left(\mathrm{U} \mathrm{g}^{-1}(\mathrm{FW}) \mathrm{min}^{-1}\right)$ activities in microshoots of strawberry plantlets (cv. 'Solnechnaya polaynka') cultivated in vitro with different mechanocomposite concentrations during the shoot multiplication (SMS, after $60 \mathrm{~d}$ ), shoot elongation (SES, after $105 \mathrm{~d}$ ) and rooting stages (RS, after $135 \mathrm{~d}$ ).

\begin{tabular}{|c|c|c|c|c|}
\hline Parameter & $\begin{array}{l}\mathrm{MC}^{*}, \\
\mathrm{mg} \mathrm{L}^{-1}\end{array}$ & SMS & SES & RS \\
\hline \multirow{4}{*}{ SOD } & 0.0 & $14.62 \pm 2.06 \mathrm{bc}$ & $27.67 \pm 0.93 b$ & $13.49 \pm 0.18 \mathrm{a}$ \\
\hline & 2.5 & $19.67 \pm 0.97 \mathrm{ab}$ & $30.81 \pm 0.12 \mathrm{a}$ & $14.05 \pm 0.26 \mathrm{a}$ \\
\hline & 5.0 & $20.42 \pm 4.61 \mathrm{a}$ & $30.65 \pm 0.05 a$ & $13.92 \pm 0.23 a$ \\
\hline & 10.0 & $11.49 \pm 3.23 c$ & $26.33 \pm 0.22 b$ & $10.43 \pm 0.58 b$ \\
\hline \multirow{4}{*}{ POD } & 0.0 & $0.37 \pm 0.04 \mathrm{~b}$ & $0.12 \pm 0.01 \mathrm{~d}$ & $0.91 \pm 0.55 \mathrm{a}$ \\
\hline & 2.5 & $0.42 \pm 0.09 \mathrm{~b}$ & $0.08 \pm 0.01 \mathrm{c}$ & $1.04 \pm 0.38 \mathrm{a}$ \\
\hline & 5.0 & $1.07 \pm 0.21 \mathrm{ab}$ & $0.26 \pm 0.01 \mathrm{a}$ & $0.28 \pm 0.05 \mathrm{a}$ \\
\hline & 10.0 & $1.42 \pm 0.26 \mathrm{a}$ & $0.21 \pm 0.01 \mathrm{~b}$ & $0.15 \pm 0.06 a$ \\
\hline \multirow{4}{*}{ CAT } & 0.0 & $10.8 \pm 1.3 b$ & $3.14 \pm 0.03 b$ & $1.61 \pm 0.70 \mathrm{a}$ \\
\hline & 2.5 & $10.4 \pm 2.7 b$ & $3.21 \pm 0.01 b$ & $2.96 \pm 0.92 \mathrm{a}$ \\
\hline & 5.0 & $15.1 \pm 0.4 \mathrm{a}$ & $3.43 \pm 0.05 \mathrm{a}$ & $1.82 \pm 0.06 \mathrm{a}$ \\
\hline & 10.0 & $4.5 \pm 0.4 c$ & $3.10 \pm 0.09 b$ & $2.16 \pm 0.99 \mathrm{a}$ \\
\hline 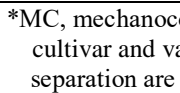 & 年 & llysis of var & $\begin{array}{l}\text { of green tea. I } \\
\text { ormed betwee }\end{array}$ & $\begin{array}{l} \pm S E(n=3) \text {. For ea } \\
\text { in a column, mean } \\
\text { nge test }(p \leq 0.05) \text {. }\end{array}$ \\
\hline
\end{tabular}




\section{Discussion}

The main task of micropropagation remains the production of a maximum number of high quality regenerants. Nutrients of medium are a critical for the improved growth and development of plants in in vitro conditions. Under stressful conditions, the overproduction of reactive oxygen species (ROS) can cause oxidative damage to plant macromolecules and cellular structures. Among the ROS, $\mathrm{H}_{2} \mathrm{O}_{2}$ is one of the major markers of oxidative stress and key signaling molecule involved in the process of differentiation, growth, and development of plants [16]. Consequently, it is important to elaborate a successful micropropagation procedure to obtain plants phenotypes with optimal physiological parameters that can survive the environmental conditions when directly placed in a greenhouse or field.

In this study, we found a significant decrease in $\mathrm{H}_{2} \mathrm{O}_{2}$ content in strawberry microshoots in response to $\mathrm{MC}$ application under in vitro propagation (Table 1). The maximum of $\mathrm{H}_{2} \mathrm{O}_{2}$ content reduction (up to 1.7 times) was observed at the end of in vitro rooting stage. This indicates enhanced resistance of plantlets to oxidative stress. It is known, enzymatic antioxidants play an important role in protection of the cell against the damaging effects of ROS. Enzyme SOD constitutes the first line of plant defense, converting superoxide anion radical $\left(\mathrm{O}_{2}{ }^{--}\right)$to $\mathrm{H}_{2} \mathrm{O}_{2}$, which is quickly metabolized by POD and CAT [17]. In current experiments, a high SOD activity and low content of $\mathrm{H}_{2} \mathrm{O}_{2}$ in microshoots at 2.5 and $5.0 \mathrm{mg}$ $\mathrm{L}^{-1} \mathrm{MC}$, especially at elongation stage, was detected suggests its role in preventing oxidative stress (Table 2). Decrease of the SOD activity at the rooting stage evidence that the plants adapt to environmental in vitro conditions. CAT and POD are the components of the antioxidant defense system involved in $\mathrm{H}_{2} \mathrm{O}_{2}$ detoxification. In this study, their activities increased in microshoots of plantlets on media supplemented with $5.0 \mathrm{mg} \mathrm{L}^{-1} \mathrm{MC}$. An increase in the activity of these enzymes indicates the synthesis of plant defense compounds against special in vitro conditions.

A similar patterns correlated with enhancing the activity of antioxidant enzymes in plants by silicon ( $\mathrm{Si}$ ) treatment were reported [18-19]. The results of study of Ajuga multiflora Bunge indicated enhancing the activity of some antioxidant enzymes such as ascorbate peroxidase (APX), CAT, and SOD on the media supplemented with Si compounds [20]. In microshoots of Ornithogalum dubium Houtt., in the presence of Si, the activity of antioxidant enzymes, ascorbate oxidase, APX, and glutathione peroxidase, significantly increased [21]. In the medicinal plant Lonicera japonica Thunb., at the salt stress, the use of Si compounds stimulated the activity of CAT and SOD [22].

The revealed increase in the activity of key antioxidant enzymes (SOD, CAT, and POD) during the multiplication, shoot elongation and in vitro rooting stages indicates the correct functioning of the mechanism of the antioxidant defense system in strawberry plants in the presence of MC.

\section{Conclusion}

In the present study, the mechanocomposite based on silicon chelates from plant raw materials can be used as a potential component of nutrient media for in vitro propagation of strawberry (cv. "Solnechnaya polaynka"), since it positively influences physiological status of the plants. $\mathrm{MC}$ modified the production and detoxification of $\mathrm{H}_{2} \mathrm{O}_{2}$ and intensifies activity of the key antioxidant enzymes (SOD, CAT, and POD) in the shoot tissues of plantlets. Determined physiological changes in microplants grown with $\mathrm{MC}$ will further contribute to successful ex vitro acclimatization of regenerants more critical stage of micropropagation. Thus, regulation of physiological status through MC addition could be a promising way to obtain better growth and development of this popular berry crop. 
In vitro propagation of $F . \times$ ananassa microplants was carried out with the financial support of the budgetary project of the Central Siberian Botanical Garden, SB RAS No AAAA-A17-1170126100515 within the framework of the State Assignment. Study of antioxidant properties mechanocomposite based on biogenic silica and green tea flavonoids at the micropropagation stages was supported by the Russian Foundation for Basic Research and the Government of Novosibirsk Region as research project No 19-44-540004. We used the material from the collection of the Central Siberian Botanical Garden, Siberian Branch of the Russian Academy of Sciences - USU_440534 "Collection of living plants indoors and outdoors".

\section{References}

1. Debnath S C, Teixeira da Silva J A 2007 Strawberry culture in vitro Fruit, Veget. Cer. Sci. Biotechnol. 11

2. Konieczny R, Libik M, Tuleja M, Niewiadomska E and Miszalski Z 2008 Acta Physiol. Plant. 3071

3. Shapolova E G, Lomovsky O I 2013 Russ. J. Bioorg. Chem. 39765

4. Zemnukhova L A, Panasenko A E, Fedorishcheva G A, Ziatdinov A M, Polyakova N V and Kuryavyi V G 2012 Inogr. Mater. 48971

5. Trofimova E G, Podgorbunskikh E M, Skripkina T S, Bychkov A L, Lomovsky O I 2018 Bulg. Chem. Commun. 5045

6. Graham H N 1992 Prev. Med. 21334

7. Ambros E V, Kotsupiy O V, Karpova E A, Trofimova E G, Zaytseva Yu G and Novikova T I 2019 Teor. Prikl. Ekol. 4116

8. Ambros E V, Toluzakova S Y, Shrainer L S, Trofimova E G and Novikova T I 2018 In Vitro Cell. Dev. Biol. Plant $\mathbf{5 4} 436$

9. Sahebi M, Hanafi M M., Azizi P 2016 In Vitro Cell. Dev. Biol. Plant 52226

10. Kulbat K 2016 Biotechnol. Food Sci. 8097

11. Gamborg O L, Eveleigh D E 1968 Can. J. Biochem. 46417

12. Bellincampi D, Dipperro N, Salvi G, Cervcone F and De Lorenzo G 2000 Plant Physiol. 1221379

13. Polesskaya O G, Kashirina E I and Alekhina N D 2004 Russ. J. Plant Physiol. 51615

14. Mehl K A, Davis M, Berger F G and Carson J A 2005 J. Appl. Physiol. 992379

15. Zhanaeva T A, Lobanova I E and Kukushkina T A 1999 Biol. Bull. Russ. Acad. Sci. 26 105

16. Hossain M A, Bhattacharjee S, Armin S M, Qian P, Xin W, Li H Y, Burritt D J, Fujita $\mathrm{M}$ and Tran L S 2015 Front. Plant Sci. 6420

17. Mitteler R 2002 Trends Plant Sci. 7405

18. Ma J F 2004 J. Soil Sci. Plant Nut. 5011

19. Liang Y, Sun W, Zhu Y-G and Christie P 2007 Environ. Pollut. 147422

20. Sivanesan I, Jeong BR 2014 Sci. World J. 20141

21. Ziv M 2010 Acta Hortic. 86529

22. Gengmao Z, Shihui L, Xing S, Yizhou W and Zipan C 2015 Sci. Rep. 512696 